\title{
Pragmatic Analysis on Social Media (Instagram)
}

DOI: https://doi.org/10.47175/rielsj.v2i1.204

\section{| Dina Hanifa ${ }^{1}$ | Sennya Nurditasari ${ }^{2}$ | Muhammad Natsir ${ }^{3}$ |}

\author{
1,2,3 Faculty of English Applied \\ Linguistics Pascasarjana \\ Department of Universitas \\ Negeri Medan, Medan, \\ Indonesia \\ ${ }^{1}$ dina.hanifa97@gmail.com, \\ ${ }^{2}$ sennyanoermuse@gmail.com, \\ ${ }^{3}$ mnatsir0@gmail.com
}

\begin{abstract}
This research was aimed to analyze the pragmatic on Social Media. The analysis was focused on the application of cooperative principles. This research was conducted by using qualitative method. The data of this study were the Netizen comments on the influencer account. The account of the influencer was Anyageraldine. The data source is taken from instagram where nowdays many people use instagram for doing communication and interaction. The writers observed and choosed the data. There were some techniques of data analysis performed, namely: determining, observing, choosing, analyzing, and drawing conclusion. Based on the data analysis conducted, it was found that the cooperative principle at 2012 - 2016 are Maxim of Quantity is 4, Maxim of Quality is 2, Maxim of Relevance is 2, and Maxim of Manner is 7. And the writers also found the Cooperative Principles at 2017 - 2020 are Maxim of Quantity is 1, Maxim of Quality is 5, Maxim of Relevance is 7 and Maxim of Manner is 2. This is influenced by the influencer's (Anya Geraldine) behaviour as we know that our behaviour make the people statements or comments, it means our behaviour also decided what the Cooperative Principles that the people will use.

KEYWORDS

pragmatic; cooperative principle; Instagram
\end{abstract}

\section{INTRODUCTION}

Language is used for communication. Language is a social fact, a kind of social contract. It exists not in an individual, but in a community (Bauer, 2007). A language is a system of conventional vocal signs by means of which human beings communicate. This definition has several important terms, each of which is examined in some detail in the following sections. Those terms are system, signs, vocal, conventional, human, and communicate (Algeo, 2010). Language is an essential part of the linguistic field. Linguistics is concerned with human language. Human language is only one way in which people communicate or collect knowledge about each other. Many linguists have contributed to this wider field. Campbell (2002) argues that early developments in linguistics have been seen as part of philosophy, rhetoric, logic, psychology, biology, pedagogy, poetry, and religion, making it impossible to distinguish the history of linguistics from intellectual history in general, and as a result, work in the history of linguistics has also led to the general history of ideas. That's why the language can be changed and developed. Moreover today the technology is more developed and the people much do the interaction by technology like social media and there are mix language culture.

Social media is a computer-based technology that facilitates the sharing of ideas, thoughts and information through the development of virtual networks and communities. By design, social media is internet-based and provides users with quick electronic communication of content. Content includes personal information, documents, videos and photos. Users engage 
in social media via computers, tablets or smartphones via web-based software or web applications, often using them for messaging purposes. One of the social media is Instagram. Instagram is a well-known mobile online photo and video sharing social network service with over 500 million active users a day. It allows users to capture their own memory in any environment, choose an image filter type, and share it with Instagram or forward it to other social networking sites such as Facebook and Twitter. Users can set up personal information on their home pages in Instagram and view it by publishing posts. It's a community to make friends, too. Users will like images that catch their eyes and communicate with their friends in the comments section. Instagram has become an inseparable part of everyday life now.

In this study the writers want to analyze pragmatic on social media (instagram). Grice (1975) states that a speech can be understood by the reader clearly if the speech matched with four maxims, that are the maxim of quantity, quality, relevance, and manner. So, the writer is interested to analyze about the deviation of cooperative principles which occurs in Netizen Comments Instagram.

\section{LITERATURE REVIEW}

\section{Pragmatics}

Pragmatics refers to the study of the relationship between language and context that is grammatical or encoded in the structure of the language (Levinson, 1983:9). It means that pragmatics is the study of the relationship between language and meaning that is important to the writing of grammars; in another book, Parker (1986:11) notes that pragmatics is the study of how language is used to communicate. Centered on Mey (2001:6)pragmatics is an analysis of the use of language in human communication as defined by the state of society.

In another explanation, Yule (1996:4) argues that the pragmatics are the study of the relationship between linguistic forms and the users of forms. In this three-part distinction, only the pragmatics allow the study of humans. The benefit of studying language through pragmatics is that you can talk about people's intended meanings, their assumption of intent or objectives, and the kind of action (for example, asking) they perform when they speak.

\section{The Cooperative Principles}

Wijana maintains that in natural contact, it can be assured that a speaker attempts to articulate his speech as he wants to express something to his hearer, and he hopes that his hearer will be able to understand what is being conveyed (1996: 45). So the speaker always seeks to make his speech important to the context, straightforward and easy to understand, strong and succinct, and always straight forward. For example, someone would use the expression "help!" and can you help me ?" in various circumstances and needs.

Grice (1975) states that in the arrangement to do the cooperative principles, a speaker has to obey the four conversational maxims as follows.

a) Maxim of Quantity Leech states that the maxim of quantity is making your contribution as informative as is required (1993: 11).

For examples :

(a) My neighbor is pregnant

(b) My woman neighbor is pregnant

In utterance (a), beside its being concise, it does not make deviation from the fact. Everybody knows that only women can be pregnant. So, the element "woman" in utterance (b) is plentiful. The word "pregnant" in (b) propagated the utterance. The presence of "woman" in (b) does not necessarily explain the things that is clear. This case is contrary to the maxim of quantity. 
b) Maxim of Quality

Different from maxim of quantity which hooks the contribution amount, the maxim of quality is related with the contribution quality of speaker in the conversation. The maxim of quality contains the advice so that the speaker gives the right contribution and say the real thing.

"Make your contribution one is true, specifically: (i) do not say what you believe to false (ii) do not say that for which you lack adequate evidence (Levinson, 1983:101).

For examples :

(a) Saya makan sate ayam atau kambing - Ayam berkepala kambing

(b) Smoking damages your health for sure

The utterance in (a) is a deviation of the maxim of quality because there is an aim to make a joke, even though the utterance (b) has an understanding that the speaker made the statement by the meaning to make pressure that smoking disturbs the healthy. This case is based on the medical proof known by large social life. So, utterance (b) fulfills the maxim of quality.

c) The Maxim of Relevance

The maxim of relevance obliges every speaker to give a contribution of relevance with the problem being told. To make it clear, pay attention to the example given by Levinson (1983 - 102) as follows :

A: Can you tell me the time?

B: Well, the milkman has come.

The dialogue above is a conversation between someone and his friend. The answer of B is not relevant with A's question, but this way can be understood based on the assumption that the utterance of $\mathrm{B}$ is relevant. $\mathrm{B}$ answered A's question indirectly, that is with the utterance "well, the milkman has come". B pronounces it because $B$ thinks that $A$ knows the milkman tradition who always come at the time A known. The conclusion is A understands indirectly the answer of B because B's answer can be understood by A, so B's answer matches with the maxim of relevance.

d) Maxim of Manner

The maxim of manner obliges every speaker to tell something logically, indistinctly and not plentifully. Grice gives examples of the utterance which does not obey the maxim of manner ( 1975: 55) as follows

(a) Miss X produced a series of sounds that corresponded closely with score of sweet home.

compared to:

(b) Miss X sang home sweet home.

Utterance (a) does not match with the maxim of manner because the utterance contains the plentiful expression in using words and it expresses something indirectly, compared to utterance (b) which matches with the maxim of manner because it is simple, direct and not plentiful in using words.

\section{Sosial Media}

Philip Kotler and Kevin Lane Keller (2016) state that social media is a platform used by users to exchange text, pictures, sound and video information with other people and businesses, and vice versa. Social networking in its present form started to evolve in the 1980s under the form of the Bulletin Board System (BBS), UseNet and the Internet Relay 
Chat. These services, while not referred to as social media, are considered to be precursors to their modern form. What is more specifically referred to as social media is the collection of resources that began to emerge in the 1990s. One of the first sites to be launched in 1995 was eBay. In 1997, the word web log, coined by Jorn Barger and later shortened to the blog by Peter Merholz, came to light. However the first services to use these names emerged in 1999 with the arrival of Live Journal and blogger.com. The next seven years saw the emergence of several services that are widely used at present, such as Wikipedia and Trip Advisor, in 2001. Then, in 2003, Skype and Word Press made their debut. After that in 2004, Facebook, which is currently the most widely used and widely used social media site, was launched. In 2005, YouTube was launched, and a service called Twitter started operating the following year. And now there are so many social media used.

\section{Instagram}

Instagram is a visual stage of online networking. Instagram is commonly regarded as the new social networking site for photo-sharing (Chante et al., 2014; Salomon, 2013). Essentially, Instagram is a mobile-based application that allows users to take pictures or photographs, apply various editing techniques to change the appearance of images, and instantly share them with friends on different social networking sites (Hochman \& Schwartz, 2012). While the application was only launched in 2010, it has developed steadily and steadily. In 2013, it was reported that Instagram had 100 million users, and approximately 4 billion images were uploaded and displayed (Abbott et al., 2013).. The platform has more than 400 million diverse clients and is owned by Facebook. It is used by a large number of its clients to post travel, form, sustenance, workmanship and comparable subjects. The stage is often known by its impressive platforms and the altering highlights of video and photography. Around 95 percent of Instagram clients use Facebook in addition.

\section{RESEARCH METHODS}

The objective of this study is to analyze pragmatic on social media (instagram) which analyze about the deviation of cooperative principles which occurs in Netizen Comments Instagram. This research was conducted by using qualitative method. Qualitative research method is defined as a research procedure which produces descriptive data in the form of words written or spoken of the person (Bogdan and Taylor, 1975:5 in Moleong, 2002:3). In line with the statement, Kirk and Miller (1986:9) as cited by Moleong (2002:3) define that qualitative research method is specific tradition in social science, which fundamentally relies on the observation of humans in its own region and relate to the person in a language and terminologies. The data of this study were the Netizen comments on the influencer account. The account of the influencer was Anyageraldine. The data source is taken from instagram where nowdays many people use instagram for doing communication and interaction. The data is compared netizen comments between at $2012-2016$ and $2017-2020$. The writers take the data from 30 comments which is choosen randomly. There were some techniques of data analysis performed, namely: determining, observing, choosing, analyzing, and drawing conclusion.

\section{RESULTS AND DISCUSSION}

In this finding, the writers discuss only the deviation of cooperative principles which are the maxims of quantity, quality, relevance and manner. 
Table of Data Result

At 2012 - 2016

\begin{tabular}{clc}
\hline No. & Maxim & Frequency \\
\hline 1. & Quantity & 4 \\
2. & Quality & 2 \\
3. & Relevance & 2 \\
4. & Manner & 7 \\
& Total & 15 \\
\hline
\end{tabular}

\begin{tabular}{clc} 
At $2017-2020$ & \\
\hline No. & \multicolumn{1}{c}{ Maxim } & Frequency \\
\hline 1. & Quantity & 1 \\
2. & Quality & 5 \\
3. & Relevance & 7 \\
4. & Manner & 2 \\
& Total & 15 \\
\hline
\end{tabular}

\section{Data Analysis}

In the Netizen Comments, the writers will analyze the cooperative principles as follows: Netizen comments at $2012-2016$

\begin{tabular}{|c|c|c|c|c|}
\hline \multirow[t]{2}{*}{ No. } & \multicolumn{2}{|c|}{ Comment } & \multirow[t]{2}{*}{ Maxim } & \multirow[t]{2}{*}{ Explanation } \\
\hline & Indonesian & English & & \\
\hline 1. & $\begin{array}{c}\text { Cantik } \\
\text { Bangeet }\end{array}$ & Very Beautiful & $\begin{array}{l}\text { Maxim of } \\
\text { Relevance }\end{array}$ & $\begin{array}{l}\text { This comment matches to the maxim } \\
\text { of relevance because the comment } \\
\text { gives her/his opinion about the } \\
\text { picture of Anya Geraldine and the } \\
\text { opinion/comment is relevance to the } \\
\text { picture. }\end{array}$ \\
\hline
\end{tabular}

\begin{tabular}{|c|c|c|c|c|}
\hline 2. & $\begin{array}{c}\text { Owalah } \\
\text { cabe- cabe an }\end{array}$ & $\begin{array}{l}\text { The coquettish } \\
\text { woman, you } \\
\text { are! }\end{array}$ & $\begin{array}{l}\text { Maxim of } \\
\text { Manner }\end{array}$ & $\begin{array}{l}\text { This comment matches to the maxim } \\
\text { of manner because the comment is } \\
\text { about attitudes of Anyageraldine }\end{array}$ \\
\hline 3. & $\begin{array}{l}\text { Nyanyaaaa } \\
\text { emesshhh } \\
\text { sukakk }\end{array}$ & $\begin{array}{l}\text { Nyanya, you } \\
\text { are so cute. } \\
\text { Love it! }\end{array}$ & $\begin{array}{l}\text { Maxim of } \\
\text { Relevance }\end{array}$ & $\begin{array}{l}\text { This comment matches to the maxim } \\
\text { of relevance because the comment } \\
\text { gives her/his opinion about the } \\
\text { picture of Anya Geraldine and the } \\
\text { opinion/comment is relevance to the } \\
\text { picture. }\end{array}$ \\
\hline
\end{tabular}

\begin{tabular}{|c|c|c|c|c|}
\hline 4. & Alay bangsat & $\begin{array}{l}\text { Too much, } \\
\text { Bitch! }\end{array}$ & $\begin{array}{l}\text { Maxim of } \\
\text { Manner }\end{array}$ & $\begin{array}{l}\text { This comment matches to the maxim } \\
\text { of manner because the comment is } \\
\text { talking about the attitude of } \\
\text { Anyageraldine }\end{array}$ \\
\hline 5. & $\begin{array}{c}\text { Persahabatan } \\
\text { yang sangat } \\
\text { fantastis }\end{array}$ & $\begin{array}{l}\text { A fantastic } \\
\text { friendship }\end{array}$ & $\begin{array}{l}\text { Maxim of } \\
\text { Quantity }\end{array}$ & $\begin{array}{l}\text { This comment matches to the maxim } \\
\text { of quantity because the comment is } \\
\text { fact and it provides information } \\
\text { related with the picture. }\end{array}$ \\
\hline 6. & Kaya tante & Like aunty & $\begin{array}{l}\text { Maxim of } \\
\text { Manner }\end{array}$ & $\begin{array}{l}\text { This comment matches to the maxim } \\
\text { of manner because the comment is }\end{array}$ \\
\hline
\end{tabular}




\begin{tabular}{|c|c|c|c|c|}
\hline & & & & $\begin{array}{l}\text { talking about the attitude of } \\
\text { Anyageraldine }\end{array}$ \\
\hline 7. & $\begin{array}{l}\text { Cantik } \\
\text { banget kak } \\
\text { kalo pake } \\
\text { kacamata }\end{array}$ & $\begin{array}{l}\text { So beautiful } \\
\text { with glasses } \\
\text { sis }\end{array}$ & $\begin{array}{l}\text { Maxim of } \\
\text { Quality }\end{array}$ & $\begin{array}{l}\text { This comment matches to the maxim } \\
\text { of quality because this comment } \\
\text { contains the advice }\end{array}$ \\
\hline 8. & $\begin{array}{l}\text { Suka banget } \\
\text { sama style } \\
\text { nya }\end{array}$ & $\begin{array}{l}\text { Really love } \\
\text { her style }\end{array}$ & $\begin{array}{l}\text { Maxim of } \\
\text { Quantity }\end{array}$ & $\begin{array}{l}\text { This comment matches to the maxim } \\
\text { of quantity because the comment is } \\
\text { fact and it provides information } \\
\text { related with the picture. }\end{array}$ \\
\hline 9. & $\begin{array}{l}\text { Ini zaman } \\
\text { belum } \\
\text { numbuh, } \\
\text { kalau } \\
\text { sekarang } \\
\text { mah mantap }\end{array}$ & $\begin{array}{l}\text { This era has } \\
\text { not yet grown, } \\
\text { if now it is } \\
\text { steady }\end{array}$ & $\begin{array}{l}\text { Maxim of } \\
\text { Quantity }\end{array}$ & $\begin{array}{l}\text { This comment is talk about } \\
\text { anyageraldine in the past and now. } \\
\text { So this comment matches to the } \\
\text { maxim of quantity }\end{array}$ \\
\hline 10. & Bungkus dah & Wrap it up & $\begin{array}{l}\text { Maxim of } \\
\text { Manner }\end{array}$ & $\begin{array}{l}\text { This comment means that the person } \\
\text { really like Anyageraldine so he want } \\
\text { to be with Anyageraldine. This } \\
\text { comment matches to maxim of } \\
\text { manner because it talks about the } \\
\text { attitude. }\end{array}$ \\
\hline 11. & $\begin{array}{l}\text { Kenapa sih } \\
\text { pelit banget }\end{array}$ & $\begin{array}{c}\text { Why? You are } \\
\text { very stingy }\end{array}$ & $\begin{array}{l}\text { Maxim of } \\
\text { Manner }\end{array}$ & $\begin{array}{l}\text { This comment matches to the maxim } \\
\text { of manner because the comment is } \\
\text { talking about the attitude of } \\
\text { Anyageraldine }\end{array}$ \\
\hline 12. & $\begin{array}{l}\text { Bacot u } \\
\text { bitch! }\end{array}$ & $\begin{array}{l}\text { Too much } \\
\text { talking you } \\
\text { are! Bitch! }\end{array}$ & $\begin{array}{l}\text { Maxim of } \\
\text { Manner }\end{array}$ & $\begin{array}{l}\text { This comment matches to the maxim } \\
\text { of manner because the comment is } \\
\text { talking about the attitude of } \\
\text { Anyageraldine }\end{array}$ \\
\hline 13. & $\begin{array}{c}\text { Tatapan mu } \\
\text { itu loh }\end{array}$ & Your stare & $\begin{array}{l}\text { Maxim of } \\
\text { Manner }\end{array}$ & $\begin{array}{l}\text { This comment matches to the maxim } \\
\text { of manner because the comment is } \\
\text { talking about the attitude of } \\
\text { Anyageraldine }\end{array}$ \\
\hline 14. & $\begin{array}{l}\text { Semoga } \\
\text { menjadi } \\
\text { model } \\
\text { professional } \\
\text { di eropa dan } \\
\text { amerika }\end{array}$ & $\begin{array}{l}\text { Hopefully } \\
\text { become a } \\
\text { professional } \\
\text { model in } \\
\text { Europe and } \\
\text { America }\end{array}$ & $\begin{array}{l}\text { Maxim of } \\
\text { Quality }\end{array}$ & $\begin{array}{l}\text { This comment matches to the maxim } \\
\text { of quality because this comment } \\
\text { contains the hopeness }\end{array}$ \\
\hline 15. & $\begin{array}{c}\text { Kalau mau } \\
\text { liat siapa } \\
\text { orang itu liat }\end{array}$ & $\begin{array}{l}\text { If you want to } \\
\text { see who that }\end{array}$ & $\begin{array}{l}\text { Maxim of } \\
\text { Quantity }\end{array}$ & $\begin{array}{l}\text { This comment matches to the maxim } \\
\text { of quantity because this comment } \\
\text { relates to the fact that people can be }\end{array}$ \\
\hline
\end{tabular}




$\begin{array}{cc}\text { siapa } & \text { person is, look } \\ \text { temannya. } & \text { at his friend }\end{array}$

temannya. at his friend evaluated by their friends or environtment

Netizen comments at $2017-2020$

\begin{tabular}{|c|c|c|c|c|}
\hline \multirow[t]{2}{*}{ No. } & \multicolumn{2}{|c|}{ Comment } & \multirow[t]{2}{*}{ Maxim } & \multirow[t]{2}{*}{ Explanation } \\
\hline & Indonesian & English & & \\
\hline 1. & $\begin{array}{c}\text { Nih body goals } \\
\text { namanya }\end{array}$ & $\begin{array}{l}\text { This is called } \\
\text { body goals }\end{array}$ & $\begin{array}{l}\text { Maxim of } \\
\text { Relevance }\end{array}$ & $\begin{array}{l}\text { This comment matches to the maxim } \\
\text { of relevance because the comment } \\
\text { gives her/his opinion about the } \\
\text { picture of Anya Geraldine and the } \\
\text { opinion/comment is relevance to the } \\
\text { picture. }\end{array}$ \\
\hline 2. & $\begin{array}{c}\text { Lari Bareng } \\
\text { yuk }\end{array}$ & $\begin{array}{l}\text { Let's run } \\
\text { together }\end{array}$ & $\begin{array}{l}\text { Maxim of } \\
\text { Relevance }\end{array}$ & $\begin{array}{l}\text { This comment matches to the maxim } \\
\text { of relevance because the maxim of } \\
\text { relevance obliges every speaker to } \\
\text { give a contribution of relevance with } \\
\text { the problem being told. And the } \\
\text { comment is relevant with the posts. }\end{array}$ \\
\hline 3. & Ini istriku & $\begin{array}{c}\text { This is my } \\
\text { wife }\end{array}$ & $\begin{array}{l}\text { Maxim of } \\
\text { Quantity }\end{array}$ & $\begin{array}{l}\text { Beside its being concise, it does not } \\
\text { make deviation from the fact. } \\
\text { Everybody knows that only women } \\
\text { can be a wife. This case is contrary } \\
\text { to the maxim of quantity. }\end{array}$ \\
\hline 4. & $\begin{array}{l}\text { Keep humble } \\
\text { kak Anya luv }\end{array}$ & $\begin{array}{l}\text { Keep Humble } \\
\text { Sister Anya, } \\
\text { Love }\end{array}$ & $\begin{array}{l}\text { Maxim of } \\
\text { Quality }\end{array}$ & $\begin{array}{l}\text { This comment matches to the maxim } \\
\text { of quality because this comment } \\
\text { contains the advice }\end{array}$ \\
\hline 5. & $\begin{array}{l}\text { Kek nya ini } \\
\text { postingan lebih } \\
\text { indah dari } \\
\text { semua } \\
\text { postingan yang } \\
\quad \text { ada }\end{array}$ & $\begin{array}{l}\text { This is like } \\
\text { the most } \\
\text { beautiful } \\
\text { posts ever }\end{array}$ & $\begin{array}{l}\text { Maxim of } \\
\text { Relevance }\end{array}$ & $\begin{array}{l}\text { This comment matches to the maxim } \\
\text { of relevance because the comment } \\
\text { gives her/his opinion about the } \\
\text { picture of Anya Geraldine and the } \\
\text { opinion/comment is relevance to the } \\
\text { picture. }\end{array}$ \\
\hline 6. & $\begin{array}{l}\text { Hijrah mbak } \\
\text { lebih cantik } \\
\text { berjilbab } \\
\text { tenang liatnya, } \\
\text { asli cahayanya } \\
\text { terpancar }\end{array}$ & $\begin{array}{l}\text { Move on sis, } \\
\text { more } \\
\text { beautiful in } \\
\text { wearing } \\
\text { hijab, your } \\
\text { brightening is } \\
\text { real }\end{array}$ & $\begin{array}{l}\text { Maxim of } \\
\text { Quality }\end{array}$ & $\begin{array}{l}\text { This comment matches to the maxim } \\
\text { of quality because this comment } \\
\text { contains the advice }\end{array}$ \\
\hline
\end{tabular}




\begin{tabular}{|c|c|c|c|}
\hline 7. Lagi galau nih & confusing & $\begin{array}{l}\text { Maxim of } \\
\text { Relevance }\end{array}$ & $\begin{array}{l}\text { This comment matches to the maxim } \\
\text { of relevance because the maxim of } \\
\text { relevance obliges every speaker to } \\
\text { give a contribution of relevance with } \\
\text { the problem being told. And the } \\
\text { comment is relevant with the picture } \\
\text { of Anya Geraldine. }\end{array}$ \\
\hline
\end{tabular}

\begin{tabular}{|c|c|c|c|c|}
\hline 8. & $\begin{array}{l}\text { Ulah ngalamun } \\
\text { wae atuh teh, } \\
\text { hehehe bisi } \\
\text { treh menua }\end{array}$ & $\begin{array}{c}\text { Don't } \\
\text { daydream sis, } \\
\text { wkwk you } \\
\text { can become } \\
\text { old }\end{array}$ & $\begin{array}{c}\text { Maxim of } \\
\text { Quality }\end{array}$ & $\begin{array}{l}\text { This comment matches to the maxim } \\
\text { of quality because this comment } \\
\text { contains the advice }\end{array}$ \\
\hline 9. & $\begin{array}{l}\text { Anya bagus } \\
\text { gini banyakin } \\
\text { prestasi ya, } \\
\text { gak usah carik } \\
\text { - carik sensasi, } \\
\text { lebih kelas } \\
\text { kamu gini }\end{array}$ & $\begin{array}{c}\text { Anya is } \\
\text { better like } \\
\text { this, make } \\
\text { more } \\
\text { performance, } \\
\text { don't look for } \\
\text { sensation. } \\
\text { You're more } \\
\text { class like this }\end{array}$ & $\begin{array}{c}\text { Maxim of } \\
\text { Quality }\end{array}$ & $\begin{array}{l}\text { This comment matches to the maxim } \\
\text { of quality because this comment } \\
\text { contains the advice }\end{array}$ \\
\hline
\end{tabular}

\begin{tabular}{|c|c|c|c|c|}
\hline 10. & $\begin{array}{l}\text { Lagunya enak } \\
\text { ditambah } \\
\text { modelnya juga } \\
\text { cantik....sempu } \\
\text { rna }\end{array}$ & $\begin{array}{l}\text { The song is } \\
\text { nice plus the } \\
\text { model also } \\
\text { beautiful....pe } \\
\text { rfect }\end{array}$ & $\begin{array}{l}\text { Maxim of } \\
\text { Relevance }\end{array}$ & $\begin{array}{l}\text { This comment matches to the maxim } \\
\text { of relevance because the comment } \\
\text { gives her/his opinion about the } \\
\text { picture of Anya Geraldine and the } \\
\text { opinion/comment is relevance to the } \\
\text { picture. }\end{array}$ \\
\hline 11. & $\begin{array}{c}\text { Cantik ka } \\
\text { tertutup }\end{array}$ & $\begin{array}{l}\text { Beautiful sis, } \\
\text { it's closed }\end{array}$ & $\begin{array}{l}\text { Maxim of } \\
\text { Relevance }\end{array}$ & $\begin{array}{l}\text { This comment matches to the maxim } \\
\text { of relevance because the comment } \\
\text { gives her/his opinion about the } \\
\text { picture of Anya Geraldine and the } \\
\text { opinion/comment is relevance to the } \\
\text { picture. }\end{array}$ \\
\hline
\end{tabular}

\begin{tabular}{cccc} 
12. Sangar arek iki & $\begin{array}{c}\text { This is so } \\
\text { fierce }\end{array}$ & $\begin{array}{c}\text { Maxim of } \\
\text { manner }\end{array}$ & $\begin{array}{l}\text { This comment matches to the maxim } \\
\text { of manner because the comment is } \\
\text { talking about the attitude of } \\
\text { Anyageraldine }\end{array}$ \\
13. Bikin meriang & $\begin{array}{c}\text { Make a } \\
\text { feverish }\end{array}$ & $\begin{array}{c}\text { Maxim of } \\
\text { Manner }\end{array}$ & $\begin{array}{l}\text { This comment matches to the maxim } \\
\text { of manner because the comment is } \\
\text { talking about the attitude of } \\
\text { Anyageraldine }\end{array}$ \\
14. Flawless & So Flawless \\
sis & Manget kak & Relevance & $\begin{array}{l}\text { This comment matches to the maxim } \\
\text { of relevance because the comment } \\
\text { gives her/his opinion about the } \\
\text { picture of Anya Geraldine and the }\end{array}$ \\
\hline
\end{tabular}




\begin{tabular}{cccl}
\hline 15. Jangan lupa & Don't forget \\
$\begin{array}{c}\text { istirahat siang } \\
\text { mine }\end{array}$ & $\begin{array}{c}\text { Maxim of } \\
\text { to have break } \\
\text { lunch mine }\end{array}$ & $\begin{array}{l}\text { opinion/comment is relevance to the } \\
\text { picture. }\end{array}$ \\
\hline $\begin{array}{l}\text { This comment matches to the maxim } \\
\text { of quality because this comment } \\
\text { contains the advice }\end{array}$
\end{tabular}

From the analysis above the writers found that there is difference cooperative principles on the netizen comments between at 2012-2016 and 2017-2020. This is influenced by the influencer's (Anya Geraldine) behaviour as we know that our behaviour make the people statements or comments, it means our behaviour also decided what the Cooperative Principles that the people will use.

\section{CONCLUSION}

After determining the data, observing, choosing the data, analyzing the data and discussing the result, the writers would like to present the conclusion of this research entitled A Pragmatic Analysis on Social Media (Instagram). After analyzing the data of Cooperative Principle, the writer accomplished to the conclusion that In netizen comments on Social Media (Instagram) of Anyageraldine. There were 30 comments which is choosen randomly by the writers. And from the comments the writers found the cooperative principle at 2012 - 2016 are Maxim of Quantity is 4, Maxim of Quality is 2, Maxim of Relevance is 2, and Maxim of Manner is 7. And the writers also found the Cooperative Principles at 2017-2020 are Maxim of Quantity is 1, Maxim of Quality is 5, Maxim of Relevance is 7 and Maxim of Manner is 2. This is influenced by the influencer's (Anya Geraldine) behaviour as we know that our behaviour make the people statements or comments, it means our behaviour also decided what the Cooperative Principles that the people will use.

\section{REFERENCES}

Akram, W., R.Kumar. (2018). A Study on Positive and Negative Effects of Social Media on Society. International Journal of Computer Sciences and Engineering, 5 (10), 347 - 354.

Algeo, J. (2010). The origins and development of the English language (6 th. Ed): wadsworth, City.

Bauer, Laurie. (2007). The Linguistics Student's Handbook. Edinburgh University Press.

Bogdan. (1992). Qualitative Research for Education. California: Pearson A \& B.

Campbell, Lyle. (2002)."The History of Linguistics." Blackwell Publishing Online.

Grice, H. P. (1975). Logic and Conversation. In P. Cole, \& J. L. Morgan. (Eds.), Syntax and Semantics, Vol. 3, Speech Acts (pp. 41-58). New York: Academic Press.

Haryani, Sri. (2017). A Pragmatic Analysis of English Advertisements a Case Study, 3, 22-32. Moleong, Lexy. (2002). Metodologi Penelitian Kualitatif. Bandung: PT. remaja Rosdakarya. Natsir, M., Saragih, B., Mira, PSA., \& Dewi, R . (2020). Language Change in Social Media (Instagram). Randwick International of Social Science (RISS) Journal, 1 (2), 394 - 401.

Page, R, et al. (2014). Researching Language and social media: A Student Guide. Routledge. Digital. 